\title{
$72^{m s}$ VERGADERING VAN HET BESTUUR,
}

\author{
GEHOUDEN TE 'S GRAVENHAGE
}

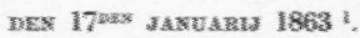

Tegenwoordig de heeren Cornets de Groot, Bleeker, Gallois, Keyzer, Brunsveld van Hulten, Hoffran, Smissaert, Willer, Wintgens en de tweede Secretaris.

De notulen der vorige vergadering worden gelezen en goedgekeurl.

De Voorzitter berigt dat de heeren Dr. G. Simons, H. A. van de Wall Bake, Mr. F. G. Fontein, Dr. D. L. van Hattum en H. J. Koenen, hun ontslag hebben genomen als leden des Instituuts.

Tot leden des Instituuts worden voorgedragen en benoemd de heeren G. S. de Veer, J. C. de Kock van Leeuwen, F. C. Rose, J. F. Roux, Mr. H. M. van Andel en M. Nijhoff, allen te 's Gravenhage.

De Voorzitter deelt een brief mede van den heer Baron Sloet van de Beele, houdende kennisgeving dat hij zijne benoeming tot lid van het Instituut heeft aangenomen.

Daarna deelt hij mede dat in antwoord op de circulaire des Bestuurs een tal van kennisgevingen zijn ontvangen van leden hier te lande, die verklaard hebben deel te willen nemen aan de werkzaamheden van eene of meer der afdeelingen. - Wordt besloten van deze brieven het noodige gebruik te maken en ze vervolgens in het archief te deponeren.

1 Tengevolge van het aan het slot dezes vermelde besluit van het Bestuur, worden voortaan verslagen van hetgeen in de Bestuursvergadering verhandeld is, in de "Bijdragen" opgenomen. 
Voorts berigt de Voorzitter, dat blijkens ontvangen mededeelingen de besturen der afdeelingen aldus zijn zamengesteld:

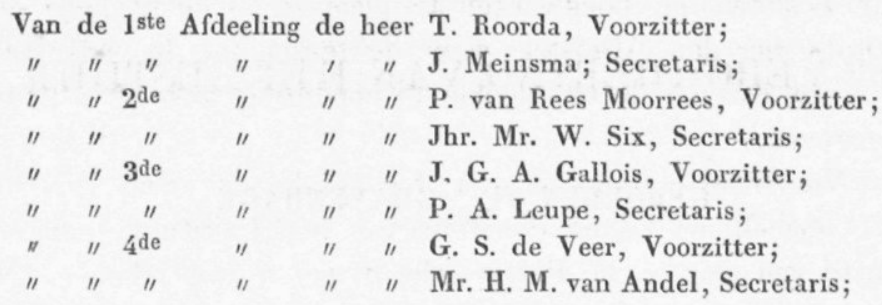

en dat door de $1^{\text {ste }}$ en $3^{\text {de }}$ Afdeeling tevens ontwerpen van instructie ter goedkeuring aan het Bestuur zijn ingezonden.

$\mathrm{Na}$ indeeling bij deze afdeelingen van de zich daartoe aangemeld hebbende leden wordt, op voorstel van den Voorzitter, besloten dat deze, zoodra van de $2^{\text {de }}$ en $4^{\text {de }}$ afdeelingen gelijke ontwerpen zullen ontvangen zijn, met de Voorzitters der afdeelingen eene vergadering zal houden, ten einde die ontwerpen van instructie in onderling verband te overwegen en deswege rapport aan het Bestuur uit te brengen.

De Voorzitter berigt, dat de $3^{\text {de }}$ Afdeeling ook nog aan de overweging des Bestuurs heeft onderworpen de vraag, of aan de leden der afdeelingen, die buiten 's Gravenhage zijn gevestigd, voor het bijwonen der afdeelingsvergaderingen ook vergoeding voor reis- en verblijfkosten zal verleend worden.

Deze vraag wordt door de Vergadering in ontkennenden zin beslist, daar $1^{\circ}$. zij geen termen vindt tot uitbreiding van den tot dusver gevolgden regel, om alleen vergoeding van reiskosten te verleenen aan hen, die, krachtens een mandaat der gezamenlijke leden van het Instituut, als leden des Bestuurs zijn opgetreden en als zoodanig bepaalde verpligtingen hebben op zich genomen, tot vervulling van welke zij zich van hunne woonplaats moeten verwijderen; en $2^{\circ}$. het ook niet gebruikelijk is eenig defroyement toe te staan aan hen, die uit eigen beweging de algemeene vergaderingen van het Instituut bijwonen.

De Voorzitter deelt mede, dat zijn ingekomen drie brieven van den Minister van Koloniën, waarvan twee ten geleide van boekwerken en een met uitnoodiging om van de stukken, die voortaan van Gouvernementswege ter openbaarmaking zullen worden afgestaan, een tiental exemplaren of overdrukken aan den Minister te doen toekomen, en het het verzoek om in- 
middels nog vijf exemplaren te ontvangen van het onlangs door het Instituut uitgegeven rapport omtrent Nieuw Guinea. Wordt besloten de boekwerken te plaatsen in de boekerij des Instituuts en den Minister voor de toezending te bedanken, met berigt dat aan laatstgemelde uitnoodiging gevolg zal worden gegeven.

De Voorzitter brengt daarna ter sprake de vraag van den heer D. Scheltema lid en donateur van het Instituut, omtrent het uitgeven der oude Bataviasche Statuten van 1642. - Na eenige mededeelingen en inlichtingen daaromtrent door de heeren Brunsveld van Hulten en Keyzer, wordt besloten die statuten met de noodige geschiedkundige ophelderingen in de Bijdragen des Instituuts op te nemen.

In verband met deze opname, wordt door den heer Keyzer mededeeling gedaan van het in druk verschijnen der derde aflevering van de Bijdragen en van de voorhanden bouwstoffen voor de volgende aflevering.

Nog wordt door den heer Keyzer, ter voldoening aan de hem gedane opdragt, een voorstel gedaan betrekkelijk het tarief der honoraria, voor stukken in de Bijdragen opgenomen, volgens art. 24 van het reglement. - Na eenige discussie wordt besloten als regel aan te nemen, dat voor hetgeen geacht kan worden in de termen te vallen van vertalingen en afschriften 4 gl. per vel druks zal kunnen worden gevalideerd, - voor hetgeen gerangschikt kan worden onder gemengd werk $8 \mathrm{gl}$. en voor geheel eigen werk $12 \mathrm{gl}$. per vel druks, met voorbehoud om in zeer enkele gevallen die honoraria te verhoogen tot 5,10 en $15 \mathrm{gl}$.

De Voorzitter berigt, dat is ingekomen een brief van den heer A. M. Coster te Paramaribo, waarbij deze meldt, dat hij aan de uitnoodiging om mededeeling van bijzonderheden omtrent de boschnegers - hem op voorstel van den heer Scheltema gedaan - gevolg zal geven onder bijvoeging van photographische afdrukken van deze negers.

De Voorzitter berigt dat, blijkens een ontvangen schrijven van den Voorzitter der $3^{\text {de }}$ Afdeeling, aan deze door den heer P. A. Leupe is aangeboden de beschrijving van een togt naar Nieuw Guinea in 1705, welk stuk echter gebleken is bij de $2^{\text {de }}$ Afdeeling te huis te behooren. - Wordt besloten dit stuk aan laatstgemelde Afdeeling te zenden, met verzoek het Bestuur te willen voorlichten omtrent de vraag, of het al of niet wen- 
schelijk moet geacht worden die beschrijving op te nemen in de Bijdragen des Instituuts.

De Voorzitter deelt verder mede, dat de boeken des Instituuts thans ten dienste der afdeelingen herwaarts zijn overgebragt en daarvan, een catalogus zal vervaardigd worden.

Nog deelt hij mede, dat bij het Bestuur is ontvangen een exemplaar van het Verslag van het 17de Landhuishoudkundig Congres te Middelburg gehouden en doet opmerken, dat daarin veel wetenswaardigs voorkomt omtrent den landbouw in de koloniën. - Dit werk wordt geplaatst in de boekerij des Instituuts.

Door den heer Gallois wordt ter tafel gebragt de begrooting voor het Instituutsjaar $1862-1 \_63$, welke na de vereischte toelichtingen wordt gearresteerd.

Naar aanleiding dezer toelichtingen, wordt verder besloten aan de Commissarissen van het Instituut te Batavia te schrijven nopens de belangen der inrigting aldaar, ook met opzigt tot het toetreden van de leden in Nederl. Indië tot de gestichte afdeelingen.

Aan de $4^{\text {de }}$ Afdeeling wordt opgedragen, te overwegen in hoever de belangen des Instituuts in onze West-Indische Koloniën behartigd kunnen worden.

Door den heer Hoffman wordt aan het Instituut aangeboden een exemplaar van de door hem bezorgde uitgave van het fac-simile van den Japanschen tekst, der door Japan met Nederland, Rusland, Engeland, de Vereenigde Staten van NoordAmerika en Frankrijk in 1858 gesloten traktaten.

Op voorstel van den heer Bleeker wordt voorts nog besloten verslagen van het verhandelde in de Bestuursvergaderingen in de Bijdragen van het Instituut op te nemen.

Niets meer aan de orde zijnde, wordt de vergadering gesloten. 